\title{
The Ecotourism Perception of Graduate and Postgraduate Tourism Students for Antalya Destination
}

\author{
İlker Günay ${ }^{1}$, Zeki Akınci ${ }^{2}$ \\ ${ }^{1}$ Akdeniz University, Institute of Social Sciences, Master Student \\ Akdeniz University, Faculty of Tourism, Tourism Management, Antalya, Turkey 07058 \\ E-mail:1ilkergunay@outlook.com,2zakinci@akdeniz.edu.tr >
}

\begin{abstract}
Ecotourism, a new term in tourism literature, is defined as an approach that sustains using natural sources while preserving them in the context of ensuring their sustainability and accordingly economic development of local residents by providing them tourism activities while preventing from natural, social and cultural degradation. The comprehension of ecotourism phenomenon plays an important role for tourism students especially for the ones who are going to take part in decision maker positions in the future. The present study is aimed to explore Akdeniz University undergraduate and postgraduate students' perception of ecotourism and Antalya destination. The questionnaire contains 24 items to measure students' vacation preferences, their considerations about ecotourism and ecotourism perceptions for Antalya destination. The questionnaire is administered to a total of 227 tourism students, 197 undergraduate, 30 postgraduate. Data gathered from 227 students are tested with specific statistical analyses methods and the results are considered as beneficial for the literature. According to the results, $53.3 \%$ of participants define ecotourism as "a tourism that explains nature and teaches it practically" and $47.1 \%$ of them define it as "a tourism that includes nature trips and related activities". It is determined that there is a significant difference between the perceptions of students who have participated in ecotourism activities before and the perception of the ones who haven't. In addition, the perception mean of the students who have participated in ecotourism activities is higher than the perception mean of the others.
\end{abstract}

Keywords: Ecotourism, Tourism Students, Tourism Education, Antalya Destination

\section{Introduction}

The change in the consumption demands of the tourists has caused to occur studies about varying touristic products and alternative tourism types emulously to the "sea-sand-sun" concept (Kıllıc and Kurnaz 2010). As a result of the local people's renting their own homes to the tourists who came to Alps, ecotourism (it is suggested by Hector Ceballos - Lascurain) has occured and it means "getting pleasure from nature and know the value of the nature" (Bozok and Özdemir Yllmaz 2008).

Ecotourism,which is a type of tourism bases on increasing awareness about protecting the nature and cultural differences and creating alternative work areas for local people, has the least affects on physical,economical and sociocultural environment (Kasalak and Akıncı 2015). In the Turkey's Tourism Strategy 2023 which is featured by The Ministry of Culture and Tourism, they give an importance to ecotourism and mentione about some plans in this area (Soyak 2013). This study consists of four main parts; literature search, methods, findings and results and suggestions.

\section{Ecotourism}

As a result of the change in the consumption demands of the tourists after 1990s has caused to occur ecotourism which is more sustainable than mass tourism as environmentally and culturally. The tourism tpyes such as ecotourism, cultural tourism,trekking,nature tourism, agrotorism, conference tourism, health\&spa tourism, religional tourism, adventure and sports tourism have became upward trends in recent years (Soyak 2013). The concept of special interest tourism is used as the synonym of trip, social tourism, ecotourism, educational tourism, environment tourism and sustainable tourism concepts (Uluçeçen 2011).

United Nations Economic and Social Council decleared the year 2002 as the "Year of Interantional Ecotourism" (Kuter and Ünal 2009). Within the frame of Year of Interantional Ecotourism, World Tourism Organization made a search in Germany, Canada, Spain, Italy and England and it showed us that the tourists who are interested in ecotourism are ranging in age from 30 to 59, high income earner, highly trained, interested in gastronomy and culture (Kılıç and Kurnaz 2010).

International Torurism Community (TIES 2006) defines the ecotourism as "the tourism which protects the environment, increases the welfare level of local people and is sensitive to the natural areas" (Bozok and Özdemir Yllmaz 2008). In their study while Kasalak and Akıncı (2015) defining the ecotourism as "the tourism which protects the environment, increases the welfare level of local people 
and a travel to the natural areas. Ceylan (2001) defines it as a strategy which helps in protecting the natural settlements and developing the local people.

Ecotourism is seen like a bridge between the ecotourists and the local people because it helps local people economically and so they give importance to their own cultural values and protect them. Also,they interact with each other socioculturally.If ecotourism is planned correctly, economic, environmental and sociocultural negative affects can be decreased (Kasalak and Akınci 2015). In some studies about ecotourism, it is determined that there are two types of ecotourism; soft ecotourism and hard ecotourism. According to Weaver ve Opperman the ideal one is hard ecotourism in which participants contact with the nature intensively and in long term. On the other hand, soft ecotourism is a type of tourism in which participants contact with the nature in short term but more frequently. In the study of Weaver (2005), the diffrences between the soft ecotourism and hard ecotourism are shown in the Table 1 (Bozok and Özdemir Yılmaz 2008).

Table 1: The differences between soft ecotourism and hard ecotourism

\begin{tabular}{lr}
\hline Hard (Active, Deep) & Soft (Passive, Shallow) \\
Strong environmental commitment & Moderate or superficial environmental commitment \\
Enhancive sustainability & Steady state sustainability \\
Specialized trips & Multi-purpose \\
Long trips & Short trips \\
Small groups & Larger groups \\
Physically active & Physically passive \\
Physical challenge & Physical comfort \\
No services expected & Services expected \\
Deep interaction with nature & Shallow interaction with nature \\
Emphasis on personal experience & Emphasis on mediation \\
Make own travel arrangements & Rely on travel agent and tour operators \\
\hline
\end{tabular}

Source: Weaver 2001

Bozok and Özdemir Yılmaz (2008) said that ecotourism would be unimaginable, if it was not sustainable. Cause it has occurred due to sustainability principles and so it is the key concept for the sustainable tourism.

\section{Antalya and the Tourism}

In Antalya the tourism sector has started to improve since 1960s, and it became the most important tourism destination with its natural and human geography properties in both Turkey and the World (Sarl 2007). By year 2015, 41.617 .000 (TÜIK 2016) tourists have come to Turkey and 11.911 .000 tourists have come to Antalya (KTM 2016). As it also understood from these results, 28,62 percent of the total tourists who visit Turkey come to Antalya. So, three out of every ten tourists come to Antalya. Antalya has a lot of natural beauties such as beaches, caves, natioanal parks, forests, fountains, lakes, highlands and mountains (Kervankıran and Bulut 2015).

Antalya is in Western Mediterranean Region and in this area it enables investment opportunities for rural and ecologic agriculture with its uncorrupted nature, wide flora and endless welcomeness. So, this area provides a basis for variable ecotourism activities. Some of these activies are; trekking, photo safari, agritourism, ornitotourism, observation of plants and animals, diving, rafting, spelaeology, paragliding,sailing and gastronomy (BAKA 2012).

\section{Objectives of the Study}

In this study the researchers tried to find the answers of the question stated below.

1. What are the holiday preferences of the undergraduate and postgraduate students'?

2. What does it mean the concept "ecotourism" for them?

3. Why do the people prefer ecotourism?

4. What is the perception level of tourism students about the ecotourism in Antalya?

\section{Materials and Methods}

The research conducted is one of the quantitative research methods. The quantitative research is a type of research in which pre-prepared questions are used to make quantitative 
comments and generalization. In this research type by using samples,quantitative results are obtained which represent the universe. And so, statistical and mathematical analyses can be made about these restlts.

This reserch investigates the perception of Akdeniz Universtiy Faculty of Tourism Grade 3 and Grade 4 students and Institute of Social Sciences Department of Tourism and Hotel Management postgraduate students about ecotourism in Antalya. The survey method was used to collect required data. The questions were prepared literally by using the master thesis of Taş (2012). This survey is 2 pages and consists of 24 questions. The first four questions are about the demographic properties of the students. The other questions are like that: How often do they travel? With whom do they travel? What were the purposes of their travelling? What does "ecotourism" mean for them? Have they ever experienced ecotourism? And if they have experienced, what kind of ecotorism activities have they preferred?

On the second page, the students were asked to answer 15 questions by using five point likert scale "1strongly disagree and 5- strongly agree". In this study the participants were Akdeniz Universtiy Faculty of Tourism Grade 3 and Grade 4 students and Institute of Social Sciences Department of Tourism and Hotel Management postgraduate students. The number of the population in this departments were 859 in 2014-2015 Academic Year. The survey is conducted on a voluntary basis and the number of the participants were 227. According to Yazıcıoğlu and Erdoğan (2004), at least 204 participants are enough among 859students. If parametric analyses will be made, at least 30participants should be in each group (Ross 2004). The population and the samples were determined by searching and investigating the datas via survey method.The results were analyzed via SPSS program.Within the frames of this research, the datas related to demographic factors were evaluated via using frequency, percent values and arithmetic means. The T-test and ANOVA analysis were used to determine whether the perception of the students about ecotourism vary due to their demographic properties or not.

\section{The Hypotheses of the Research}

This reserch includes the hypotheses related to the perception of tourism students about ecotourism.

H1 There is a significant difference between the gender of tourism students and their perception of ecotourism.

H2 There is a significant difference between the age of tourism students $(20-25,26$ and over) and the perception of ecotourism.

H3 There is a significant diffirence between tourism students' situation to attend in ecotourism activities and their perceptions of ecotourism.

H4 There is a significant diffirence between education of tourism students (Grade 3,Grade 4 and postgraduate) and their ecotourism perceptions.

\section{Results}

This section includes the findings derived from the survey questionnaire conducted for the present research. In order to analyze the data obtained from the survey, different statistical methods were used.

In order to determine socio-demographic characteristics of those who participated in the survey, participants are asked about their gender, age and level of education they study. Socio-demographic characteristics of the sample are presented in Table 2.

Table 2. Socio-demographic characteristics of the sample

\begin{tabular}{|c|c|c|c|}
\hline & & $N$ & $\%$ \\
\hline \multirow[t]{2}{*}{ Gender } & Female & 123 & 54,2 \\
\hline & Male & 104 & 45,8 \\
\hline \multirow[t]{3}{*}{ Age } & Between 20-25 years of age & 177 & 78,0 \\
\hline & 26 and over & 50 & 22,0 \\
\hline & Grade 3 & 98 & 43,2 \\
\hline \multirow[t]{3}{*}{ Level Of Education } & Grade 4 & 99 & 43,6 \\
\hline & Postgraduate & 30 & 13,2 \\
\hline & Total & 227 & 100,0 \\
\hline
\end{tabular}


$54,2 \%(n=123)$ of our sample is composed of female participants; $78 \%(n=177)$ of the participants are between $20-25$ years of age and $43,6 \%$ ( $n=99)$ of the sample is senior university students (Table 3 ).

In Table 3, 4 and 5, the data regarding the travel frequency of participants, with whom they travel, the purpose of travel, what the concept of ecotourism means for them, whether they engaged in ecotourism activity and in the case they did, their motives behind this preference are presented.

Table 3. Travel preferences of participants

\begin{tabular}{|c|c|c|c|}
\hline & & $N$ & $\%$ \\
\hline \multirow{5}{*}{$\begin{array}{c}\text { How often do they } \\
\text { travel? }\end{array}$} & More than 3 times a year & 93 & 39,6 \\
\hline & 2 times a year & 49 & 20,9 \\
\hline & 1 time per year & 47 & 20 \\
\hline & 3 times a year & 38 & 16,2 \\
\hline & Total & 227 & 100,0 \\
\hline \multirow{5}{*}{$\begin{array}{c}\text { With whom do you } \\
\text { travel? }\end{array}$} & *Friends & 104 & 45,8 \\
\hline & *Alone & 87 & 38,3 \\
\hline & * With my family & 54 & 23,8 \\
\hline & * Acquaintance visit & 102 & 44,9 \\
\hline & * Holiday (Sea - Sand - Sun) & 94 & 41,4 \\
\hline \multirow{6}{*}{$\begin{array}{l}\text { What were the } \\
\text { purposes of their } \\
\text { travelling? }\end{array}$} & * Education & 80 & 35,2 \\
\hline & * Seeing natural beauties & 67 & 29,5 \\
\hline & * Seeing cultural and historical attractions & 40 & 17,6 \\
\hline & * Business / Congress & 33 & 14,5 \\
\hline & * Health and thermal & 31 & 13,7 \\
\hline & * Festival (Other) & 1 & 0,4 \\
\hline
\end{tabular}

* Expressions for multiple options marked in proportion to all participants ( $\mathrm{N}=227$ ).

$39,6 \%(n=93)$ of our participants reported that they travel more than 3 times a year. When the answers given to the question "With whom do you travel?" are examined, it is seen that $45,8 \%(n=104)$ stated that they prefer travelling with their friends, while $38,3 \%(n=87)$ reported that they prefer traveling alone. When purposes of travel are questioned, it is seen that visiting acquaintance $(n=102)$, holiday (sea-sand-sun) $(n=94)$, education $(n=80)$, seeing natural beauties $(n=67)$ and seeing cultural and historical attractions $(\mathrm{n}=40)$ are reported as purposes of travel respectively by $44,9 \%, 41,1 \%, 35,2 \%$, $29,5 \%$ and $17,6 \%$ of the participants (Table 3 ).

Table 4. Findings relevant to the literature

\begin{tabular}{clcc}
\hline & & $N$ & $\%$ \\
\hline & $*$ A tourism type that explains nature and teaches it practically. & 121 & 53,3 \\
& * A tourism type that includes nature trips and related activities. & 107 & 47,1 \\
What does & *A tourism type that provides relief and escaping from stress & 60 & 26,4 \\
"ecotourism" & *A tourism type that helps to local and regional development. & 49 & 21,6 \\
mean for you? & ** A tourism type that inconvenient, offering simple and & 40 & 17,6 \\
& straightforward, facilities. & 36 & 15,9 \\
& * A tourism type that provides realization of sporting activities. & 31 & 13,7 \\
\hline
\end{tabular}

When the participants are asked to choose among the descriptions of ecotourism given to them, which they think best reflect the concept, it is seen that the descriptions that are chosen by the majority of the participants are the components of the ecotourism concept. The result that students who participated in the survey chose two descriptions which are utterly important descriptions for the concept of ecotourism shows that students are sensitive to environmental issues and environmentally conscious. Furthermore, only 31 respondents chose the statement that "a tourism which offers an expensive and fashionable travel", which does not fit the description and nature of ecotourism concept shows that the concept is well understood by students (Taş 2012). 
Table 5. Participants' previous experience with ecotourism and the motives of those who engaged in ecotourism activities previously

\begin{tabular}{clcc}
\hline & & $\boldsymbol{N}$ & $\mathbf{\%}$ \\
\hline Have they ever & No & 139 & 61,2 \\
experienced & Yes & 88 & 38,8 \\
ecotourism? & Total & $\mathbf{2 2 7}$ & $\mathbf{1 0 0 , 0}$ \\
& * Being alone with the nature & 38 & 43,2 \\
& * Moving away from the city's noise and fresh air & 33 & 37,5 \\
& * Curiosity & 28 & 31,8 \\
What kind of & * Experiencing a different holiday and getting rest & 27 & 30,7 \\
ecotourism & * Passion of adventure & 26 & 29,5 \\
activities have & *Learning about natural beauties of the region & 23 & 26,1 \\
they & * Perform activities i never done before & 22 & 25 \\
preferred? & * Participate in transhumance activities and festivals & 19 & 21,6 \\
& * Discover yourself & 18 & 20,5 \\
& *To deal with mountaineering and extreme sports & 15 & 17
\end{tabular}

* Expressions for multiple options marked in proportion to those found in ecotourism activities (N=88)

$38,8 \%(n=88)$ of those who participated in the survey indicated that they engaged in eco- tourism activity before. Those who indicated that they engaged in eco-tourism activity before reported "being alone with the nature" $(43,2 \%, n=38)$, "moving away from the city's noise and fresh air" $(37,5 \%, n=33)$, "curiosity" (31,8\%, n=28), "experiencing a different holiday and getting rest" (30.7\%, $n=27)$, "passion of adventure" $(29.5 \%, \mathrm{n}=26)$, "learning about natural beauties of the region" $(26.1 \%, \mathrm{n}=23)$, "Perform activities i never done before" $\quad(25 \%, \mathrm{n}=22)$ and "participate in transhumance activities and festivals" $(21.6 \%, n=19)$ as the reasons for why they preferred ecotourism (Table 5).

In order to determine the mean and standard deviation of the statements of participants regarding their "perception of ecotourism", for all of the subjects who participated in the survey ( $N=227)$, on the basis of their statements the mean and standard deviation were calculated and presented in Table 6.

Table 6. Mean and standard deviations of participants' statements regarding their perception of ecotourism

Table 6. Mean and standard deviations of participants' statements regarding their perception of ecotourism

\begin{tabular}{|c|c|c|c|}
\hline & & $X$ & $s d$ \\
\hline 1 & With its natural beauties, Antalya and its around is a suitable area for ecotourism & 4,26 & 0,76 \\
\hline 2 & $\begin{array}{l}\text { As well as ecotourism, Antalya has sufficient tourism potential in terms of } \\
\text { other }\end{array}$ & 4,15 & 0,82 \\
\hline 3 & $\begin{array}{l}\text { Numbers of centre of attraction and tourist destinations are sufficient for the } \\
\text { development of alternative tourism in Antalya.. }\end{array}$ & 3,80 & 1,07 \\
\hline 4 & $\begin{array}{l}\text { The environment should be protected and monitored for development of ecotourism in } \\
\text { Antalya. }\end{array}$ & 4,38 & 0,79 \\
\hline 5 & $\begin{array}{l}\text { Increasing of the numbers of protected areas around Antalya has contributed to the } \\
\text { conservation of natural structures. }\end{array}$ & 3,68 & 1,16 \\
\hline 6 & $\begin{array}{l}\text { Necessary infrastructure and superstructure works are realized to to achieve the } \\
\text { desired level of alternative forms of tourismbin Antalya. }\end{array}$ & 3,41 & 1,05 \\
\hline 7 & $\begin{array}{l}\text { Antalya and its surroundings are appropriate and sufficient access facilities for } \\
\text { ecotourism. }\end{array}$ & 3,48 & 1,10 \\
\hline 8 & $\begin{array}{l}\text { More flights to domestic and international routes in Antalya and Gazipaşa Airports } \\
\text { provide increasing of the alternative tourism potential in the region of Antalya. }\end{array}$ & 3,97 & 0,98 \\
\hline 9 & $\begin{array}{l}\text { The number of professional travel agencies which are interested in ecotourism and } \\
\text { alternative forms of tourism is enough. }\end{array}$ & 3,05 & 0,98 \\
\hline 10 & $\begin{array}{l}\text { Promotion of Antalya destination and region is done enough for the introduction of } \\
\text { alternative tourism in the region. }\end{array}$ & 2,83 & 1,08 \\
\hline 11 & $\begin{array}{l}\text { Recreational facilities in the transport network, services such as road signs and } \\
\text { information boards are insufficient. }\end{array}$ & 3,04 & 1,06 \\
\hline
\end{tabular}


12 Antalya and its around existing facilities (infrastructure) and ecological accommodation 3,04 was very limited.

13 In the region of Antalya, locals have negative attitudes toward tourists.

14 Guides are not equipped have not enough information about the historical,

natural and cultural features of Antalya region.

15 Ministry of Tourism and Culture does not make enough publicity and information about ecotourism.

16 People have not enough information about Perception of Ecotourism

According to the findings, among all statements, "For development of ecotourism in Antalya, the environment should be protected and monitored" $(x=4,38)$ had the highest mean and it was followed by these statements respectively: "With its natural beauties, Antalya and its around is a suitable area for ecotourism" $(x=4,26)$, "As well as ecotourism, Antalya has sufficient tourism potential in terms of other alternative types of tourism" ( $\mathrm{x}=4,15)$. The statement that "In the region of Antalya, locals have negative attitudes toward tourists" had the lowest mean $(x=2,72)$ (Table 6). Reliability analysis of the scale employed in the present research reveals Cronbach's alpha value of 0,61 , which shows that the scale is a reliable measure.

In order to investigate whether there is a significant difference between respondents' perception of ecotourism and their gender, we conducted a t-test. Result of the analysis revealed no significant difference between male and female respondents in terms of their perception of ecotourism $(p<0,05)$ (Table 7).

Table 7. The effect of gender on the perception of ecotourism

\begin{tabular}{lccccc}
\hline & \multicolumn{2}{c}{ Female } & \multicolumn{2}{c}{ Male } \\
& Mean & & \multicolumn{2}{c}{$(N=104)$} & $p$ \\
& & $S D$ & Mean & $S D$ & 0,784 \\
\hline Perception of Ecotourism & 3,49 & 0,35 & 3,47 & 0,44 & \\
\hline
\end{tabular}

In order to see whether there is a significant difference between the perception of ecotourism and the age of the participants, a t-test is conducted. The analysis revealed that there is no statistically significant difference in the perception of ecotourism between the participants who are in 20-25 age range and those who are at the age of 26 and over $(\mathrm{p}<0,05)$ (Table 8).

Table 8. The effect of age on the perception of ecotourism

\begin{tabular}{lccccc}
\hline & \multicolumn{2}{c}{$\begin{array}{c}20-25 \text { age range } \\
(N=177)\end{array}$} & \multicolumn{2}{c}{$(N=50)$} & $p$ \\
& Mean & $S D$ & Mean & $S D$ & 0,612 \\
\hline Perception of Ecotourism & 3,49 & 0,39 & 3,46 & 0,41 & \\
\hline
\end{tabular}

In order to see whether there is a significant difference between participant's perceptions of ecotourism and having an ecotourism experience a t-test is conducted. The analysis revealed that there is a statistically significant difference in terms of the perception of ecotourism between those who have previous ecotourism experience and those who did not engage in ecotourism activities before $(p<0,01)$ (Table 9).

Table 9. The effect of previous experience with ecotourism on the perception of ecotourism

\begin{tabular}{|c|c|c|c|c|c|}
\hline & \multicolumn{2}{|c|}{$\begin{array}{c}\text { Experienced } \\
(N=88)\end{array}$} & \multicolumn{2}{|c|}{$\begin{array}{c}\text { Inexperienced } \\
(N=139)\end{array}$} & \multirow[t]{2}{*}{$p$} \\
\hline & Mean & $S D$ & Mean & $S D$ & \\
\hline Perception of Ecotourism & 3,58 & 0,35 & 3,42 & 0,41 & $0,003^{*}$ \\
\hline
\end{tabular}

In order to compare the statements regarding the perception of ecotourism and the participants' level of education (university junior, senior and graduate student), analysis of variance (ANOVA) is conducted. In order to see which level of education produces this significant difference, Scheffe test is conducted. 
Table 10. The effect of education on the perception of ecotourism

\begin{tabular}{|c|c|c|c|c|c|c|}
\hline \multicolumn{7}{|c|}{ Educational Background } \\
\hline & $\begin{array}{c}\text { Grade } 3 \\
(N=98) \\
(A)\end{array}$ & $\begin{array}{c}\text { Grade } 4 \\
(N=99) \\
(B)\end{array}$ & $\begin{array}{c}\text { Postgraduate } \\
(N=30) \\
(C)\end{array}$ & $F$ & $p$ & $\begin{array}{l}\text { Significant } \\
\text { Difference }\end{array}$ \\
\hline Perception of Ecotourism & 3,58 & 3,38 & 3,51 & 6,75 & $0,001^{*}$ & $A-B$ \\
\hline
\end{tabular}

As can be seen in Table 10, regarding the ecotourism perception there is a difference between junior and senior university students, the analysis reveals no significant difference among other variables $(\mathrm{p}=0,001<0,01)$.

\section{Discussion}

Results and recommendations of this study, aimed to find the perception of ecotourism for Antalya destination of Akdeniz University Tourism Faculty's 3rd and 4th grade students and Tourism and Hotel Management Department of Social Sciences Institute's graduate students, can be summarized as follows;

In this study, students' answers of questions about holiday preferences are examined.

It is understood that a large number of students, more than 3 times, mostly with his friends and they go on a trip alone per year and their travel purpose are generally friendly visit, vacation (sea - sand - sun) and education. These results are expected when we consider the formation of the universe from students. Another question posed to the participants is their expression of ecotourism. More than half of the participants in the answers given to this question $(53,3 \%)$ understand ecotourism as "a tourism that explains nature and teaches it practically" and Another part of $47.1 \%$ understand ecotourism as "a tourism that includes nature trips and related activities". The answers overlap with the Taş's (2012) study and students' high rate choices of these two options means that they are sensitive to environment, and they have high level of environmental awareness.

$38.8 \%$ of the students who participated in this study, they state that they have participated in eco-tourism activities before. When we asked about preference reason or cause of eco- tourism to this participant the first five were located as "Being alone with the nature", "Moving away from the city's noise and fresh air", "curiosity", "Experiencing a different holiday and getting rest" and "passion for adventure". To test the hypothesis, the t-test (independent samples) and one way variance (ANOVA) analysis are used. The results of the hypothesis about the participants' perceptions of ecotourism (rejection / acceptance) is as follows: H1 hypothesis is rejected which in the form as: "There is a significant difference between the gender of tourism students and their perception of ecotourism". With this result, it was seen that there is no meaningful differences between Antalian students' genders and their perception of eco-tourism. H2 hypothesis in the form of "there is a significant difference between the age of tourism students $(20-25,26$ and over) and the perception of ecotourism" is rejected. In this result as the H1's result, it was seen that there is no significant effect between Antalian students' ages and their perception of ecotourism.

It has been understood before that there is a significant difference between participants who attended in ecotourism activities and who didn't attend. The average perception of ecotourism of participants who attended ecotourism activities was higher $(3,58)$ than the average perception of ecotourism of participants who didn't attend any ecotourism activity $(3,42)$. In the light of this result, hypothesis $\mathrm{H} 3$ which is "there is a significant diffirence between tourism students' situation to attend in ecotourism activities and their perceptions of ecotourism" has been accepted. According to ANOVA test has been done, there is a significant diffirence $(p<0,01)$ between 3rd grade and 4 th grade students. It has emerged that 3rd class students' perceptions were higher than 4th grade students' perceptions of ecotourism activities. As a result, hypothesis $\mathrm{H} 4$ which is "there is a significant diffirence between education of tourism students (3rd grade, 4th grade and graduate) and their ecotourism perceptions" has been accepted.

\section{Conclusion}

In the context of sustainable tourism, the recognition and applicability of ecotourism are of vital importance, as it stands out as a social, cultural and environmental alternative to mass tourism. This study 
attempts to reveal the perceptions of ecotourism among the students currently receiving tourism education, who are potential future managers and decision-makers in tourism sector. The results of this study indicate that tourism students who have participated in ecotourism activities are more conscious and have sufficient knowledge about ecotourism than do the students who have not participated in ecotourism activities and that they have sufficient knowledge of ecotourism opportunities in the destination of Antalya. Therefore, we believe that the inclusion of ecotourism in the curricula of tourism schools, along with its theoretical knowledge and practical applications, will make a significant contribution to the awareness about ecotourism among the students receiving tourism education.

As in all scientific studies, certain limitations in terms of time, costs and opportunities are involved in this study. Due to such limitations, our research could be performed in the undergraduate and postgraduate students attending the Akdeniz University Faculty of Tourism. Thus, future studies with larger samples including students from other universities are needed to make more comprehensive and detailed comparisons.

\section{References}

BAKA 2012. (West Mediterranean Development Agency). Ekoturizm Sektör Raporu. From <http://www.baka.org.tr/uploads/1349952547EKOTURiZM-SEKTOR-RAPORU- $\quad$ 11EYLUL.pdf> (Retrieved on February 28 2016)

Bozok D, Özdemir Yılmaz Ö 2008. Turistik Ürün Çeşitlendirmesi. Editor: Hacıoğlu, N. ve Avcıkurt. C, In, "Ekoturizm" Nobel Yayınları, Ankara.

Ceylan T 2001. Turizm ve Sürdürülebilir Gelişme. Anatolia: Turizm Araştırmaları Dergisi, 12: 169-177.

Kasalak M.D, Akıncı Z 2015. Ekoturizmin Yerel Halk Üzerindeki Etkilerinin Değerlendirilmesi. International Journal of Social Sciences and Education Research, 1(1): 230-239.

Kervankıran İ, Bulut E 2015. Antalya İli Turizminin Gelişimini ve Etkilerini Yerel Halk Nasıl Değerlendirmektedir?, Türk Coğrafya Dergisi, 65: 35-45.

Kılıç B, Kurnaz A 2010. Alternatif Turizm ve Ürün Çeşitliliği Oluşturmada Ekolojik Çiftlikler: Pastoral Vadi Örneği. İşletme Araştırmaları Dergisi, 2(4): 39-56.

KTM. 2016 (Antalya Provincial Directorate of Culture and Tourism). Tourism Report From 2012 to 2015.

From <http://antalyakulturturizm.gov.tr/TR,150327/aralik.html> (Retrieved on March 03 2016).

Kuter N, Ünal H E 2009. Sürdürülebilirlik Kapsamında Ekoturizmin Çevresel, Ekonomik ve Sosyo-Kültürel Etkileri. Kastamonu Üniversitesi, Orman Fakültesi Dergisi, 9 (2): 146-156. Ross M R 2004. Introduction to Probability and Statistics For Engineers and Scientists.

Elsevier Academic Press, San Diago.

Sarı C 2007. Antalya'nın Alternatif Turizm Kaynakları ve Planlaması, Yayınlanmamış Yüksek Lisans Tezi, Ankara Üniversitesi Sosyal Bilimler Enstitüsü, Ankara.

Soyak M 2013. Uluslararası Turizmde Son Eğilimler ve Türkiye'de Turizm Politikalarının Evrimi. Marmara Sosyal Araștırmalar Dergisi, 4:1-18.

Taş S 2012. Trabzon Ve Ekoturizm: Yerli Ziyaretçilerin Yöreyi Değerlendirmesine Yönelik Bir Araştırma. Yayınlanmamış Yüksek Lisans Tezi, Balıkesir Üniversitesi Sosyal Bilimler Enstitüsü, Balıkesir.

TÜIK 2016. Turizm raporu 2001-2016. From <http://www.tuik.gov.tr/PreIstatistik Tablo.do

?istab_id=1609> (Retrieved on March 03).

Uluçeçen T H 2011. Özel İlgi Turizmi: Kapsamı, Çeşitleri ve Türkiye'de Uygulanabilirliği. Yayınlanmamıș Uzmanlık Tezi, T.C. Kültür ve Turizm Bakanlığı Dış İlişkiler ve Avrupa Birliği Koordinasyon Daire Başkanlı̆̆ı, Ankara.

Weaver D B 2005. Comprehensive and Minimalist Dimensions of Ecotourism. Annals of Tourism Research, 32(2): 439-455.

Weaver D B 2001. Ecotourism. Brisbane, Australia: Wiley

Yazıcıoğlu Y, Erdoğan S 2004. SPSS Uygulamalı Bilimsel Araştırma Yöntemleri. Detay Yayıncılık, Ankara. 